7. Королюк, И.П.. Медицинская информатика: Учебник / - 2 изд., перераб. и доп. - Самара: ООО «Офорт»: ГБОУ ВПО «СамГМУ», 2012. - С. 122- 131.

8. Гусев, А.В. Медицинские информационные системы: анализ рынка / А.В. Гусев, И.П. Дуданов, Ф.А. Романов / PCWeek №47/2005. С. 38-40, http: // www. pcweek.ru/idea/article/detail.php?ID=75038

9. Гусев, А.В. Медицинские информационные системы: состояние, уровень использования и тенденции / А.В. Гусев // Врач и информационные технологии. - 2011. - №3. - С. 6-14.

10. Гусев, А.В. Обзор рынка комплексных медицинских информационных систем / А.В. Гусев // Врач и информационные технологии. - 2009 . - №6. - С. 4 - 17 , http://www.kmis.ru/site.nsf/pages/2009_obzor_kmis.htm.

11. Сайт КМИС, https://www.kmis.ru.

\title{
Аликулиев В.К. \\ Мониторинг заболеваемости челюстно-лицевой области у призывников и допризывников Азербайджана и оптимизация порядка их диспансеризации
}

Азербайджанский Медицинский Университет (Азейрбайджан, Баку)

doi: $10.18411 /$ sr-10-06-2021-02

Актуальность. Согласно эпидемиологическим данным, уровень распространённости заболеваний полости рта у подростков достигает 60\%, среди которых доминируют приобретённые заболевания, такие как кариес зубов, утрата зубов, заболевания пародонта [1]. Одной из существенных проблем в оказании стоматологической помощи является отсутствие статистических данных о структуре патологий и малочисленность каких-либо видов лечебно-профилактической стоматологической помощи [2]. Рост числа призывников с аномалиями челюстнолицевой области, которые нуждаются в оказании специализированной стоматологической и ортодонтической помощи, стал закономерным результатом недостаточной изученности структуры и особенностей врождённых и приобретённых аномалий и дефектов зубочелюстной системы у подрастающего поколения.

Эпидемиология основных стоматологических заболеваний в Азербайджане изучена достаточно хорошо, однако в имеющейся литературе не отображена четкая медицинская экспертиза стоматологического статуса призывников с врожденными аномалиями и приобретенными деформациями челюстно - лицевой области и зубочелюстной системы, сопровождающихся серьёзными функциональными нарушениями актов жевания, дыхания, глотания и речи.

Несвоевременное выявление и лечение указанных заболеваний приводят к негодности призывников к службе в рядах вооруженных сил по состоянию здоровья. В специальных нормативных актах даны указания по экспертной оценке различных видов аномалий и деформаций челюстно-лицевой области и их послеоперационных состояний у призывников [4]. Однако, при анализе статей указанного документа, касающихся стоматологического статуса призывников, не было взаимосвязи между видом патологии со степенью функциональных нарушений. Определение этой взаимосвязи позволит улучшить физические и психологические аспекты здоровья военнослужащих Азербайджанской армии.

Государственные программы по повышению эффективности профилактических и просветительских мер, а также по рациональной организации лечебного процесса позволили снизить показатели заболеваемости [4].

Исходя из этого, изучение структуры заболеваемости органов и тканей челюстно-лицевой области у лиц призывного возраста представляет научный и практический интерес для военной медицины. 
Целью исследования являлся анализ распространенности зубочелюстных аномалий у призывников и допризывников Азербайджана и оптимизация порядка их диспансеризации.

Материалы и методы. В условиях выполнения данного многолетнего обследования достаточно однородной группы призывников получены многочисленные результаты обследования состояния зубного ряда и жевательной функции 432 призывников из г. Баку и регионов Азербайджана в период с 2004 по 2008 годы; 72 истории болезни мальчиков в возрасте от 8 до 17 лет, которые обращались в одну из частных стоматологических клиник г.Баку с различными аномалиями зубочелюстной области; 95 историй болезни мальчиков в возрасте от 9 до 17 лет, которые обращались в одну из государственных стоматологических клиник г.Баку.

Результаты и их обсуждение. Проведенный анализ работы центральных и региональных медицинских комиссий службы по призыву свидетельствует о значительном количестве зарегистрированных случаев стоматологической патологии и их негативной динамике. Состояние зубного ряда у лиц призывного возраста оценивается как неудовлетворительное и характеризуется частичной или полной вторичной адентией (у 27,5\% призывников), низкой эффективностью жевательной функции (у 91\% призывников она находилась в пределах 5-46\%), которые нуждаются в оказании ортогнатической помощи. Наиболее часто встречался открытый тип прикуса (у 116 призывников, что составило 26,8\%). Также, был распространен мезиальный тип - 53 случая, что составило 12,2\%. В 16 случаях был зафиксирован дистальный тип прикуса, в 12 - ортогнатический, в 5 - перекрестный, у 4 призывников - глубокий, у 3 прямой. В то же время, у 222 призывников аномалии прикуса главным образом связаны с полной или частичной вторичной адентией, что составило $51,3 \%$.

Анализ регионального аспекта засвидетельствовал большую распространенность в районах г.Баку в сравнении с регионами Азербайджана аномалий зубочелюстного ряда после хейло- и уранопластики на $81,8 \%$, вторичной адентии разного рода - на $80,3 \%$, а макро- и микрогнатий - на 77,78\%.

Однако, учитывая разный размер выборки обследованных призывников, более информативным может быть показатель распространенности аномалий в пересчете на 100 человек. Так, частота распространенности аномалий зубочелюстного ряда после хейло- и уранопластики была выше среди призывников из регионов на 16,57 случаев, вторичной адентии разного рода - на 10,76 случаев, макро- и микрогнатий - на 7,72 случаев.

Сравнительный анализ эффективности работы стоматологических клиник частной и государственной форм собственности с учетом возраста обращения мальчиков показал, что в государственной клинике было зафиксировано значительно большее число обращений пациентов в возрасте 16-17 лет (на 27,8\% больше), а также меньший процент пациентов в возрасте 12-13 лет (на 19,3\%) в сравнении с данными частной клиники. Средняя эффективность лечения в государственной клинике была на 23,83 п.п. ниже (72,0\% эффективности лечения) в сравнении с частной клиникой (95,8\%). Специфика изученных выборок позволила сравнить эффективность работы двух клиник по лечению двух типов аномалий. Так, эффективность лечения дистального прикуса в частной клинике составляла 96,4\%, а в государственной $-57,1 \%$, что было ниже на 39,3 п.п., а успешность лечения мезиального прикуса в частной клинике $(91,2 \%)$ была выше на 24,6 п.п., в сравнении с государственной клиникой $(66,6 \%)$. Также было установлено, что с увеличением возраста обращения эффективность лечения зубочелюстных аномалий снижается, особенно в условиях государственной стоматологической клиники. 
На основании полученных данных размера фронтальной межзубной щели, степени аномалии и степени нарушения жевательной функции, были усовершенствованы диагностические критерии оценки протрузии фронтального отдела верхней челюсти. Согласно результатам проведенного исследования, у 46,7\% призывников с диагнозом протрузия фронтального отдела верхней челюсти от общего числа проанализированных был установлен размер щели более 5 мм, II степень аномалии и умеренная степень нарушения жевательной функции (от 14\% до 58\%), и они были непригодными к несению воинской службы.

Решением проблемы усовершенствования диагностических критериев и лечебной помощи при протрузии фронтального отдела верхней челюсти является использование брекет систем, позволяющих в минимальные сроки провести необходимую коррекцию прикуса. Это подчеркивает необходимость совершенствования системы стоматологической помощи, своевременной диагностики и проведения профилактики аномалий зубочелюстной области у призывников.

На основе полученных данных нами был оптимизирован порядок диспансеризации юношей допризывных возрастов (при приписке) и их медицинское освидетельствование, а также порядок диспансеризации юношей призывных возрастов (при призыве). Кроме того, был усовершенствован алгоритм диспансерного учета юношей допризывных возрастов (при первичной приписке), а также юношей призывных возрастов (при призыве). Считаем целесообразным при освидетельствовании призывников использовать предложенную карту обследования, что позволит минимизировать сроки обследования и постановки диагноза. Использование данной карты возможно в работе медицинских комиссий во всех силовых структурах.

Выводы. В результате проведенной работы были впервые выявлены уровень распространенности и структурные особенности врожденных и приобретенных аномалий челюстно-лицевой области у призывников в Азербайджане, изучена взаимосвязь степени нарушения функций жевания со степенью аномалии у призывников. Были определены объективные критерии обследования призывников, что позволило улучшить качество их медицинской экспертизы, уменьшило материальные затраты, связанные с необходимостью проведения им повторного освидетельствования. Были оптимизированы и предложены меры по организации диспансерного учета призывников, а результаты проведенных исследований использованы как при медицинской экспертизе военнослужащих, так и при освидетельствовании в системе других силовых структур.

Таким образом, построение и развитие комплекса профилактических мероприятий и высококвалифицированной специализированной стоматологической помощи в структурах военно-медицинского профиля позволяет не только выполнить своевременный набор призывников на контрактную службу, но и существенным образом повысить уровень стоматологического здоровья военнослужащих.

$$
* * *
$$

1. Селянинов А. А., Тотьмянина А. В., Подгаец Р. М. Биомеханическое сопровождение коррекции зубного ряда с применением эластопозиционеров. // Российский журнал биомеханики. - 2012. - Т. 16, № 1. - С. 57-79.

2. Образцов А.В. Социально-гигиенические аспекты стоматологической патологии у подростков, допризывников и призывников в современных условиях: дис. ... канд. мед. наук. - Москва, 2006.$154 \mathrm{c}$.

3. Приказ ФСБ РФ от 29.06.2004 N 457 (ред. от 23.03.2009) Об организации военно-врачебной экспертизы в органах Федеральной службы безопасности Статьи 54-56.

4. Проценко А.С. Состояние стоматологического здоровья студенческой молодежи Москвы и пути его улучшения: дис. ... канд. мед. наук.- Москва, 2010.- 147 с. 